\title{
Teacher Education and Co-Learning with ESD
}

\author{
A case study for developing ESD, co-learning, and global \\ partnership in Teacher Education in Denmark
}

NIELS LARSEN

\begin{abstract}
Education for a sustainable future includes, not only qualitative basic education (Goals 4 and 4.7 of the Sustainable Development Goals (SDG)) but also reorientating and transforming educational institutions such as Teacher Training Institutions (TTI) to address sustainable development and learning in a global context.TTIs have the potential to bring knowledge, skills, values and develop action competences and social learning for future generations and give hope for creating a more sustainable future. This article focuses on a cross-national partnership in TTI education, and discussions from a case study lead to an awareness of what is called three-layered cultural challenge on micro, mezzo and macro level when establishing international partnerships in education.
\end{abstract}

KEYWORDS: Co-learning; Teacher Training Institutions; global citizenship; whole institution approach; social learning and partnerships

\section{Teacher Education and ESD}

Education for a sustainable development (ESD) and the 17 development goals (SDG) includes, in its broadest sense, not only qualitative basic education (SDG goal 4), but also reorientating and transforming educational institutions such as Teacher Training Institutions (TTIS) to address sustainable development and learning. Teacher education also serves as a key agent for change in transforming education so such a future is possible (UNESCO 2005). TTIs not only have the potential to bring knowledge, skills, values and develop action competencies for future generations and give hope for creating a more sustainable future, but can also serve as guides for global partnership and citizenship.

In this article, we will examine and reflect on how teacher education can develop sustainable actions within Goals 4.7 and 17 of the SDGs. 4.7 will "... acquire knowledge and skills needed to promote sustainable development, including among others through education for sustainable development ... global citizenship, and appreciation of cultural diversity and of culture's contribution to sustainable development" (UNESCO17 2021). And in Goal 17 it is argued that: "... targeted capacity-building in developing countries to support national plans to implement all the Sustainable Development Goals, including through North-South, SouthSouth, and triangular cooperation" (UNESCO 17). 
How can TTIs develop collaboration and partnerships for cross-cultural learning with, about and for ESD and develop Global Citizenship? Especially during the Decade for Education for Sustainable Development (DESD), i.e. 2005 - 2014, the focus on how to implement Teacher Education in the sustainable development approach was started. Teacher educators and teacher institutions are considered key agents in the effort to promote ESD in all aspects (McKeown \& Hopkins 2014). Already at the end of the DESD, Teacher Education Institutions had accumulated experience, and some countries have reoriented teacher education and integrated ESD in the curriculum, pedagogy, and professional development (Hopkins \& Kohl 2020; SWEDESD 2017). Other countries, like Denmark, have started programmes that can lead to more ESD (Breiting \& Schnack 2009) and recently, teachers and student teachers in Denmark have started an ESD network (Teachers for Future). It has been a natural step to include the educational sector in the systemic vision for sustainable development especially after the introduction of the 17 development goals and accelerating climate change.

\section{Partnership and ESD}

Sustainable development is now seen as a grounding principle for cross-national or global citizenship and awareness on not only teaching about ESD in schools but also teaching and learning for ESD (Hargreaves 2008). Learning for ESD, means a direction to make a change in the educational goals for a more sustainable orientation and with the 17 Development Goals (SDG), the world now has the hollistic view for the way forward. Teacher education can make an important contribution because it can raise awareness (Goal 4.7), educate teachers, develop competences for ESD, develop networks among researchers and practitioners in education and play a key role in developing connections from a "whole school approach" to global citizenship education and intercultural understanding. The whole school approach to sustainability targets all aspects of the school, from curriculum, school governance, pedagogy, resource consumption, community outreach, curriculum development, parterships with other countries and includes, not only formal day-to-day practices, but also hidden curricula (Ferreira et al. 2006).

In this article, we shall refer to a programme from one specific teacher education institution in Denmark that integrated different approaches and partnered and collaborated with a TTI in Kenya, East Africa. This case will be the starting point for reflections and discussions on how TTIs can develop partnership as a basis for co-learning that integrates, not only ESD elements, but also establishes learning communities across different nationalities in the future (Healey et al. 2014. p. 26).

In many ways, partnerships between Kenyan and Danish educational institutions from primary to university level is a good starting point for more cross-cultural collaboration. Partnerships have many forms and many approaches (Healey et al. 2014) trying to change existing practices and structures: not only a change of mind-set but also by including cultural learning in a more authentic way to embrace the complexity of our contemporary world. This is also described in a roadmap from UNESCO that recommends establishing networks and platforms for meetings, and exchange programmes between different stakeholders to implement ESD and foster cross-national collaboration and create synergies (UNESCO 2020).

In Denmark, however, there is, as of 2021, still no national policy for integrating education for sustainable development and learning, and it is therefore up to the local TTI to integrate ESD in the curriculum. A review of ESD in the Nordic countries with a focus on Teacher Education, concluded that:

A study of the curriculum for the TE (BEK nr 186, 05/03/20181), does not reveal any explicit emphasis on sustainability in the primary subjects such as Mathematics and Danish, but a closer 
look into the secondary subjects shows that it is mentioned in one of the recent reforms of the bachelor's degree Programme in Education in March 2013... Here, sustainability is included as a learning objective for student teachers within a number of subjects. (Jònsson, P. et al. 2021/44).

The conclusion is that, until now, it is rather unclear how ESD is being implemented in Denmark compared with Kenya, the country being used in this paper as the case for partnership with Denmark ${ }^{1}$.

In 2017 Kenya adopted an "Education for Sustainable Development Policy for the Educational Sector" stating that education needs to be a place for transform and implement ESD " ... to address learning skills, perspectives and values that guide and motivate learners to seek sustainable livelihoods, participate in a democratic society, and live in a sustainable manner" (Republic of Kenya 2017, 6).

The focus in this paper is related to partnerships and the sustainable future for the TTI and its transformation to a 'whole institution approach' (see below). The paper will look at empirical experiences from a pilot project for lecturers and student exchanges, intercultural communication and ESD integration in a Danish TTI in collaboration with another TTI in Kenya. We will reflect on how it is possible to establish networking and co-learning in ESD related themes with schools and institutions in the Global South. In a feedback perspective, we will discuss, at a micro, mezzo and macro levels different challenges and reflections on how a pilot programme like this can develop more ESD-related elements for teacher education in the future.

\section{Methodology and Method}

The SDGs call for "a spirit of strengthened global solidarity." Problems that span geographical boundaries and sectors also require collaboration (UN 2015, Preamble). Partnership "focuses in particular on the needs of the poorest and most vulnerable and with participation of all countries all stakeholders and all people" It was in response to this claim that Danish University College developed and initiated a partnership and co-learning programme for teacher students at primary and lower secondary levels school in different subject modules with a developing country like Kenya: "Kenya is faced with serious domestic problems including high levels of inequality and poverty, and critical challenges due to climate change. To spur higher and sustained inclusive economic growth, Kenya needs to address these issues" (Danida 2020).

First, we will give a short overview of the Danish Initial Teacher Education, followed by a description of the essential parts of the cross-cultural teacher training programme, GLAD (Global Learning - Advanced professionalism - Dialogue). In the analysis and discussion, we will describe the outcome from the GLAD programme to relevant challenges and possibilities on how this can be a way forward for developing co-learning and global citizenship today with ESD content.

ESD and global citizenship education present a case for a social constructivist approach and a conceptualization of dynamic social learning processes. Daws (2005) argues for the concept of co-learning between teachers and students in a classroom setting. And with Daws, we can further argue that the sharing of knowledge, values and skills is essential for the cross-cultural communication of content related to ESD and the development of the SDGs.

1 News from worldsbestnews.org beginning of 2022 inform that the Ministry of Education in Denmark will meet representatives from different educational partners on how to implement and start an actionplan for ESD in the Danish school system. 
Co-learning can be described as "...a process of interactive and experimental dialogue and collaborative interaction in a particular field with specific objectives" (Law, 2011, 8(3),1-10). One of the distinctive approaches of co-learning is that it develops a 'community of practice' through situated learning (Law 2011). In that sense, the connection between co-learning, global citizenship and ESD as a situated learning environment is relevant for TTIs in the future (Gougoulakis 2019). Community of practice means in this project that teacher students and their lecturers at the TTI communicate and initiate dialogues about content related subjects, supported by a didactic-pedagogical approach as well as perspectives on intercultural understanding of sustainable development, relevant knowledge, skills, values and competences. A number of subjects like geography, social studies, sciences, and citizenship/civic education have already practiced this (Bourn et al. 2017).

\section{Danish and Kenyan Teacher Education in the GLAD Programme}

Teacher Training education ( $\left(L U 13^{2}\right.$ ) aims to provide students with knowledge, skills and values necessary to function as academically, didactically, and pedagogically competent teachers in the Danish public school system (Danish Initial Teacher Education 2013). The public teacher education (non-profit under the public administration) is institutionally situated in each of the seven administrative regions under the different University Colleges in Denmark. The Teacher Education is a four-year programme (240 ECTS) and the programme consists of the following four main elements: 1) Teacher's foundational competences (Pedagogy, and teaching profession skills and general education), 2) Main subjects (e.g. art, geography, mathematics, etc.), 3) Teaching practice and 4) Bachelor thesis.

Teaching practice is carried out in different local mostly public schools and part of the practical teacher training may be taken abroad if approved by the educational institution in Denmark. The practical teaching is divided into didactics, classroom management, relations and cooperation competences. For their Bachelor's project students carry out independent research, investigating on the basis of a professional analytic approach and present action-oriented reflections on teaching and the challenges of being a professional teacher.

The GLAD programme was piloted as an initiative from educators in Denmark between 2014 and 2017, partly supported by Danida ${ }^{3}$. The purpose of GLAD was to develop information, cross-cultural communication, exchange of the Danish teacher students to one local community school and also a TTI, cross-cultural learning with theKenyan teacher students through intercultural pedagogy and didactics focused on sustainable development in connection with teacher training education. The main activities are related to the online co-learning process - especially in geography (see later) and included direct student and lecturer exchange.

The different elements of the GLAD programme were:

- Professional development, both relative to individual subjects (e.g., geography) and in basic professionalism for the teacher profession in general including pedagogy, psychology and didactic (in Danish: Lærernes grundfaglighed).

2 From November 2020 the ministry of education in Denmark has started a discussion of a new reform for Teacher Education in Denmark: https://ufm.dk/aktuelt/pressemeddelelser/2020/filer/notat-om-udvikling-aflaereruddannelsen.pdf

3 Danida is the term used for Denmark's development cooperation, and is placed under the Ministry of Foreign Affairs of Denmark. Support for schools and others to enlighten and inform about activities, such as foreign aid, can be granted by various Danida funding sources. 
- Pedagogical and didactic theory combined with practice (advanced in-depth module).

- Conveying and communicating global themes with experience from visiting developing countries, and communication with students and teachers in developing countries.

- Focus on topics with a global outlook, such as sustainability, healthcare, the climate, etc.

- Work placement and exchange with a global view where students and lecturers from Denmark visited Kenya, while lecturers from Kenya visited Denmark.

- For the Danish teacher students: use of experiences from Kenya to promote teaching materials and learning lessons in Danish primary school in relation to their work placement (Teaching practice).

- Cooperation with local publically-funded primary schools in Kenya.

- Active use of ICT such as Skype, videos and blog-based dialogues was included in the process.

- Culture studies and mutual exchanges; for example, in connection with work placement where students were able to use their experience and knowledge from the project in the final bachelor project (BA), and in connection with profession projects ( $1^{\text {st }}$ to $3^{\text {rd }}$-year students).

The GLAD programme aimed to integrate LU 13's (Teacher education from 2013) four areas of competence which is: basic professionalism; subject specific courses (undervisningsfag); work placement for the exchange students (Danish:" praktik": three weeks in Kenya and three weeks in a Danish primary school); and a BA project. Additionally, it was possible to work with global themes in the 'advanced in-depth' module (Danish: "fordybelsesmodul"). Topics like sustainability, culture studies, and globalization and intercultural understanding were taught and discussed, and the module also offered the opportunity to test online ICT possibilities (Skype) within the field of cultural studies. The teaching materials offered possibilities for exploration of international and global teaching projects in Danish schools and voluntary Danish organizations working globally. The module also included an introduction to the school system and the teacher education in Kenya and the whole learning approach with roots in the English school system.

In short, the project had the intention of:

- Working with subject-oriented knowledge, skills and competences

- Pedagogical and educational theory (didactic) combined with school placement

- Presentation and information and teaching about and with other cultures

- Working within themes about sustainable development, health, climate, etc.

- Global view and experiences from the school placement and exchange visits

- Collaboration with local primary and lower secondary schools in Denmark and one primary school in Kenya

- Active use of ICT, such as Skype, Blogs, and social media like WhatsApp.

In all the programme involved five different educational institutions: a TTI in Denmark (UCL) and the Teacher Training College in Kenya (Muranga TTC); a work placement primary school in Kenya and two work placement primary schools in Denmark. During the process each of the Danish primary schools established partnerships with a Kenyan primary school. 
It was possible, during the three-year GLAD pilot project, to exchange six lecturers and 18 teacher students from the Danish TTI with Kenya. Four lecturers from the Kenyan Teacher Training College, and one representative from the Kenyan Institute of Curriculum Development visited Denmark. In addition to teaching, the lecturers also participated in different workshops and conferences.

\section{Co-Learning and ESD}

Co-learning is a method for the collaboration and development of competences working in the GLAD project. Co learning indicates different elements and processes, which can be illustrated in this model (figure 1.).

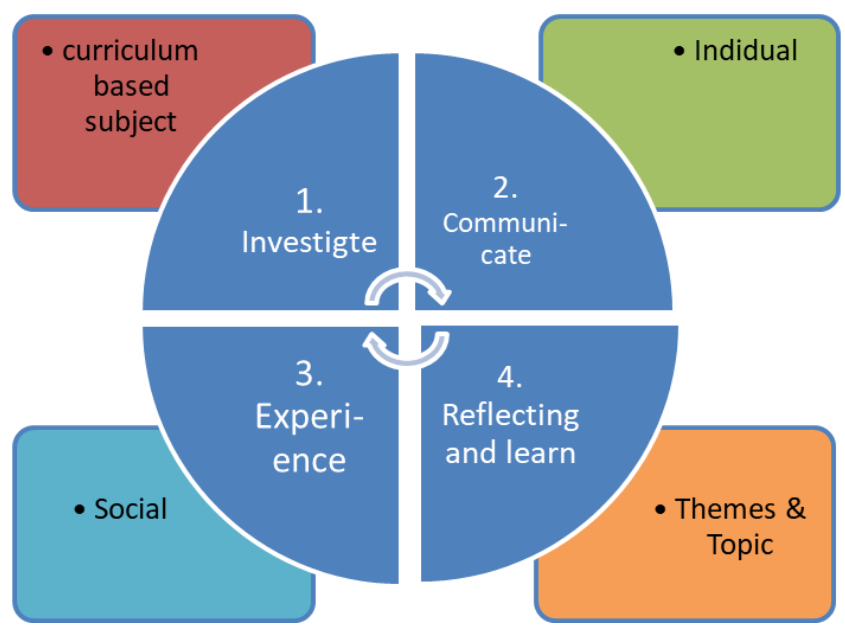

Figure 1 - Main elements in co-learning process

A main premise in co-learning is that it should not be an 'add on' but should be integrated in the curriculum, not only in the Danish TTI but also in the Kenyan TTI. Although, as mentioned above, ESD is implemented in Denmark is quite unclear how as compared with Kenya. Both partners find suitable themes and topics to work with in the exchange programme and the process. Students in both countries work individually and socially (peers or groups). During the process (the circle in the fig. 1) students work in an action-learning circle. Starting with an investigation of possibilities for curriculum-oriented knowledge, skill, and competences, this was followed up by the communication and planning of the relevant teaching activities for both the Kenyan and the Danish students. Experiences with teaching and experiences from the comparisons between Danish and Kenyan school activities, as well as the Skype meetings made it possible to reflect on learning experiences, for both the Danish and the Kenyan students, and on the differences and similarities related to the chosen themes and topics. The distictions between the steps are blurred and the inter-relationships are complex and diverse when put into practice.

The concept of co-learning has different meanings depending on the context. Either it refers to the collaboration between lectures and teacher students in a classroom or it refers to collaboration between different classes independent of time and space (online). In the GLAD project, it was decided to prioritize the common curriculum content, the social networking and teaching material outcome between teacher students from different cultures. The common themes can be core curriculum related topics, like sustainable development and innovation. Wolfgang Klafki (1996) has, for example, argued for a form of education for global 
citizenship, stressing that critical-constructive edification must take into consideration global and epochal key problems and challenges as peace, mutual global understanding, and ecological and technological challenges

In general, we can express the principles of co-learning like this: "Co-learning aims at the collaborative construction of knowledge, in which co-learners are able to expand their social networks, integrate open learning with collective research and co-author collaborative productions" (IGI Global n.d.).

Some researchers operate with a narrowly related concept called co-creation, which has been developed and examined in higher education. Bovill (2019) suggests that "one way to conceptualize co-creation is occupying the space in between student engagement and partnership, to suggest a meaningful collaboration between students and staff, with students becoming more active participants in the learning process, constructing understanding and resources with academic staff." Both concepts have in common that the content is related to and embedded in the curriculum, but in co-creation students are more involved in the partnership with teachers and in co-learning it is a student - student relationship. Research and evidence from this way of learning tell us that it is more involving, and it motivates the students more than ordinary classroom teaching.

Co-learning in cross-cultural educational meetings is often related to partnership programmes between schools from different cultures. From experiences with different school partnerships, we know that co-learning and partnerships contribute to the development of the following skills and competences among students (The National Archives n.d.):

- Ability to co-operate and to work effectively in a group to achieve common goals.

- Communication skills, such as the ability to observe closely, to listen actively and to gather information through questioning and discussion.

- Being able to detect bias, stereotypes and egocentric attitudes in oneself, in others and in the media.

- Being able to synthesize information and to imaginatively create a whole picture of a country from disparate sources of information.

- Ability to translate concern for situations in the country into appropriate, local and concrete action.

The co-learning cycle (see figure 1.) is built on the idea that, by way of co-learning, students and teachers investigate their curriculum and share common themes and topics with the partner class or partner schools. This is the first step and relates to the common topic in a simple and concrete way, thus making the task achievable. The second step is to formulate a goal for the product and the process that will match both the students' and the teachers' needs and expectations. The third step is formulating a teaching plan for the different lessons. This especially involves discussing and agreeing upon how the product will be and how it will be represented. Step four should include a clear time plan for the whole process and set some milestones where the process will be evaluated. During step four, it is essential to communicate with the partner school if it is an online process. Step five consists of a debriefing process.

Co-learning in school partnerships means that co-learning can be both face-to-face meetings when students make the exchanges and visit each other. But co-learning can also be realized at home if both partners have made a clear and joint agreement of the different stages and phases. In this process, it is often integrated with online sessions, either on Skype, Zoom or similar digital meeting platforms.

Co-learning in the GLAD project was related to the curriculum plans for TTI schools in Denmark and Kenya. The teachers from both Kenya and Denmark discussed and agreed on how 
environmental and sustainability themes could be incorportated into the process, while fulfilling curriculum requirements.

Geography was the first subject to be taken up in the GLAD programme modules, but in Denmark and Kenya lecturer in geography and the Danish lecturer in christian studies/religious education were especially active in implementing the programme. Other subjects such as art, mathematics and music were later integrated as well.

\section{Co-Learning and Geography as a Part of the Partnership}

In the following section we are referring to the 8-4-4 educational system in Kenya, meaning 8 years in primary school, 4 years in secondary school and 4 years of further education such as university.

The subject geography was, as mentioned earlier, the first subject to be piloted in the colearning methods. Later more subjets at the TTC will be included in the whole process, meaning that the co-learning will be the main methods to integrate more teachers and students in the whole partnership project.

Together with the Kenyan lecturer from TTI, the Danish lecturer made a detailed programme for the co-learning process. At primary schools (class $1-8$ ) in Kenya: social science (in Denmark geography) some of this content is based on learning from different map types, weather and climate, and climate change and life conditions in Africa. Social science also includes population, politics, social and economic issues.

At diploma level in teacher education and in secondary schools, the subject geography in Kenya is a subject classes called standard 9 - Form 3 in secondary schools. And the introduction for geography looks like this:

The study of Geography involves description and analysis of places on earth and the spatial distribution of phenomena in their varied interrelationships as they influence human activities. The subject is dynamic as well as interdisciplinary as it interrelates both with the humanities and the sciences." (Republic of Kenya. Ministry of Education. Diploma Teacher Education Syllabus Vol. 3. Kenya Institute of Education February 2008).

After the overview in the first subject, geography, it was concluded that both social science and geography were ideal for a co-learning project.

An online co-learning session is described below. During the introduction, a roadmap for the whole geography programme was decided among teachers and principals in Denmark and Kenya. It was also decided to divide the students in groups of three from each class. If possible, the teacher in geography also asked the students to participate in the students' exchange in Kenya.

1. Phase: Geographical presentation: Students from each country made a presentation from maps and Google Earth, pictures and video sequences of their country and a selfportrait including their living conditions. Students formulated questions relating to living conditions and more subject-related questions, for instance concerning infrastructure in the local area or the developmental plans for urban or rural areas.

a. Skype session 1: Students to make presentations on geographical settings of both Denmark and Kenya. Written materials and PowerPoints were shared in advance via Dropbox.

b. Skype session 2: Students to make presentations of UNs 2030 goals for sustainability comparing problems and solutions in Denmark and Kenya. 
c. Skype session 3: Students to make presentations on geography teaching in the Danish and Kenyan education system. Students were to discuss the relevance of using educational theories and discuss teaching pratice using questions like "why, what and how". What goals and what kind of methods could be used when teaching about UN's 2030 goals. How can co-learning between students from Denmark and Kenya improve the quality of practice?

2. Phase: Production of teaching materials for the subject geography, especially for primary (standard 7 and 8 in Denmark) and secondary schools Form 1 (standard 9 in Denmark). Students would discuss and include didactic theory as well. During this process, students from Denmark could suggest how students in Kenya could integrate Danish-related issues in the Kenyan teaching materials and vice versa.

3. Phase:Teaching practice using the teaching material produced in the classroom. Teacher students used the teaching material for pupils in their school practice and made video sequences of the actual use and teaching in classes. Both the Kenyan and the Danish students commented the performances and the teaching material in their respective classes. A joint interview guide was produced for the later adjustment of the whole session in the final phase 4 .

a. Skype session 4: Students from each country exchanged videos from classroom teaching practice via YouTube. The videos were used in discussions about the effectiveness of learning methods and materials used in their practices.

4. Phase: Evaluation and debriefing. Both the Kenyan students and the Danish students made small interviews with each other about their teaching and teaching materials. This was concluded by a final discussion on the quality of the teaching period and a discussion of the attained action competences and teaching performances.

a. Skype session 5: Evaluation of the co-learning project.

As shown in the above phases, the co-learning between the classes in Denmark and Kenya used ICT media such as Skype, videos and dropbox to communicate their findings, discussions and presentations. Altogether, the action-oriented co-learning programme had 1) Subject-related presentations 2) Subject-didactic related discussions 3) Intercultural discussions 4) Experience discussions from the work placements. 5) Evaluation and dissemination discussions and 6) Development of teaching material.

\section{Evaluation and Findings}

From the external evaluation made by a Danish anthropologist it was concluded that the GLAD programme had a lot of interesting elements and findings related to communication about ESD/SDGs and the development of co-learning elements in school subjects and other relevant themes like intercultural understanding in teacher education. At the end of this section we also look at the challenges from an individual, technical and institutional point of view. As well as challenges related to the educational systems in the different countries.

Students found it interesting and engaging when they made inquiries and investigated SDG's specific goals and were able to compare the Danish view with the Kenyan view: e.g. the 
quality in education (goal No. 4) but also goal No. 7: affordable and clean energy: i.e. access to renewable, safe and widely available energy sources for all and other relevant goals.

The GLAD project shows that partnership is a relationship in which all participants (students and lecturers) are actively engaged and stand to gain not only from knowledge but also from the process of learning by working together as it is concluded by Healey et al. (2014 p.7):

... that engaged student learning is positively linked with learning gain and achievement, and argues that partnership represents a sophisticated and effective approach to student engagement because it offers the potential for more authentic engagement with the nature of learning itself and the possibility for genuinely transformative learning experiences for all involved.

Partnership can essentially be seen, not only as a product, but also as a process and a way of making learning activities more than just the final outcome. Looking back at the co-learning model (figure 1), the inner circle, is all about process and the different elements outside the circle are necessary for the process (curriculum and chosen themes and topics). The personal and social aspects are related to the social learning process. Social learning is described by Keen et al."... as the collective action and reflection that occurs among different individuals and groups as they work to improve management of human and environmental interrelations" (Keen et al.2005,p.4).

Besides the general findings, the key activities between the teachers and the students in Denmark and Kenya were related to the didactic and pedagogical experiences between the two partners in different subjects such as geography. Challenges, tensions and social learning gained from the process can be related to the following issues:

\section{Subject-related communication.}

Teacher students from both sides got experience and shared different views, not only on the correct expressions and undertanding of different concepts in the diverse subjects but also differences in the way geography and social science is understood in relation to this environmental sustainability in the different curricula.

\section{Subject didactic approaches in an international dialogue and communication context.}

Dialogue between the students and the lecturers about the teaching methods and undertanding of didactics in general and in relation to specific subjects was a challenge but also a revelation for both partners. Because the lecturers had face-face meetings and exchange visits both ways (Danes to Kenya and vice versa) it was easier to get a sense of understanding, but at the same time harder for the teacher students especially for those who only communicated online.

For the Danish students, it was possible to transform subject-didactics approaches to a subject-didactic practice in a Danish school environment through the international communication process.

The teaching practice for the Danish students was possible during the whole project period because the local schools in Denmark, who offer school practice for teacher students, were open to the experience the student gained from the project and were then able to transform it didactily into practical teaching.

Social learning and patnerships are interrelated and can be sustained where there is a strong and shared relationship and shared values between the partners, and if they are able to build a committed partnership and learning community (Healey et al.2014). Partnerships can be transformed in a sustainable way and as social learning when divergent interests, 
norms, values and constructions of reality meet in an environment that is conducive to learning (Wals 2009, p. 18).

When it comes to education for sustainability it was mainly the ESD 1 approach that was practiced in the GLAD project (Vare \& Scott 2007). ESD 1 promotes informed, skilled behaviours and ways of thinking about sustainable development, which might be helpful in the short term where the need is clearly identified and agreed upon. In the GLAD project it was indicated that the content, in the communication between the teacher students from Denmark and Kenya, was related to sustainable issues like goal No. 4, about quality in education. Secondly, there should be a clear match between both countries' curricula, so students and lecturers were able to find common themes and topics.

But also, elements of ESD 2 were examined where teacher students would build capacity to think in a critical way about what experts say and could explore ideas and dilemmas and contradictions when they compared the environment and sustainability from each others' country. Teacher students asked into and tried to understand the global - local relationship when it came to environmental issues. It became more clear in the GLAD project, because teacher students from both sides now have a 'local witness and voice' to clarify and then discuss the more global issues on how to deal with the environment (content related). But also discuss the teaching practice when it comes to transforming it into the classrooms (learning process related).

During the three-year period, it was possible to integrate the GLAD project in the teaching practice, different subjects, and exchange programme for students and lecturers in a flexible way. Especially the students' trips and stay in the Kenyan schools was exciting, authentic and engaging. One example of a learning outcome for the Danish students was how to handle classroom management at a Kenyan school compared to the Danish school and in new ways this opened the teacher students' eyes to a more global view of the teacher profession. The development of different teaching materials and tools, was an element the Danish students were able to share with their Kenyan friends. In subjects like geography, the students from both sides have been challenged:

- in subject-related knowledge

- English skills

- dissemination skills

- intercultural competences

- and technology.

The subject module, geography, provided many good experiences during the programme because it integrates both the Danish and the Kenyan learning objectives from the curriculum in the co-learning process.

Other challenges can be related to the following themes:

- Competence based and not competence based educational system:

- The difference between the Kenyan and the Danish teacher education and the whole educational system in general was, however, a challenge. Kenya is in the process of rolling out a new school reform and introducing Competency Based Curriculum (CBC) in all schools: (Njeng'ere, K. D \& Lili J (2017)).

- Anglo Saxon vs. continental:

- In a broader view, there was a challenge as well, when it came to the differences between the Anglo-Saxon education system (curriculum), the continental educational system (didactic and Bildung), and this was experienced by the 
Danish students as a more test and exam-oriented education system in Kenya, but it was manageable to agree on the teaching practice assessment and evaluation form that was made between the Kenyan and the Danish partners.

- Online and internet access:

- The communication between partners, primarily because of poor internet connection in Kenya.

- Connecting the pedagogic and didactic approaches to the intercultural competences:

- During the three year pilot project it was also a challenge to the pedagogic and didactic approaches to the intercultural competences in a logical way, and it became a challenge to transform the experiences from the student exchange visits in to ESD related themes.

- At the institutional level:

- the collaboration between the TTI and the primary schools was established without problems, but the challenges were to make the programme formal as a legal partnership's agreement with real and long-lasting commitment.

The above-mentioned challenges regarding student-related, technical and more general challenges, such as the different educational systems, are often found when establishing international partnerships and co-learning between schools or TTCs between different countries (Larsen, N. et al. 2014).

\section{ESD in Teacher Education and Three-Layered Cultural Challenge}

Sustainability and sustainable development are not only environmentally and economically related but also socially and culturally related and linked to processes like partnership, social learning and co-learning especially when it comes to education and learning. Teacher Training Institutions should be advanced and experts in that sense, that is why this article is about the connection between TTI and international partnerships and development of engagement, competences and learning that makes it possible to acquire knowledge, skills and alternative ways of looking at, and take action into, a more sustainable world.

In this last section, we will elaborate and discuss the findings from the GLAD programme and look at how the learning outcome from this programme could indicate possibilities for strengthening ESD in Teacher Education in general. Analytically, we will look at micro, mezzo, and macro levels.

At micro-level, the co-learning and development of competences for sustainable development at the individual and social level are generally discussed, not only in research-related papers and in practice but also at policy level (UNECE 2012). Challenges and risks formulated as wicked problems (problems without a clear solution) are some of the issues discussed in research (Læssøe 2020; Bertschy et al. 2013; Hopkins \& Kohl 2020). Dilemmas, contradictions, visions and hopes have also been discussed in relation to co-learning (Larsen et al. 2014) and the development of competences relevant for sustainable development has been explored in practice (Vare et al. 2019). But also how education for sustainable development in action for primary and secondary teachers and mid-level decision-makers and those who work in a formal setttings has been been guided by different publications from UNESCO like ESD Sourcebook (2012). 
Experiences from the GLAD project taught us that co-learning in an international partnership needs more reflection. The different approaches to education and learning, in the different countries, must be reflected on and discussed further so that they do not negatively impact on the co-learning and collaborative experience in the class room - which is the ultimate goal of the exercise.

In the GLAD project we only examined one subject, geography. We need to reflect on how more subjects can be integrated in a cross-curricular, cross-cultural way.

Main competences towards ESD appear to have had a more solid foundation with the GLAD project. Vare et all. (2019) have mentioned more than 39 different ESD relevant competences and systematically arranged them according to the four main pillars: Learning to Know, Learning to Do, Learning to Live together, and Learning to Be, framed by Jacques Delors (1996), following "Rethinking Education - Towards a global common good" from UNESCO (2015) and latest - also a UNESCO publication: "Reimagining Our Futures Together - A new social contract for education" (2021) . These reports all mentioned collaboration and development of especially individual and social competences and awareness of cross-national competences.

However, further discussion is needed on which competences are necessary for the GLAD project to be developed in order to contribute to a deeper integration of ESD. There might be new competences needed for global solidarity and international cooperation, which the GLAD project did not prioritise. But in many ways the GLAD programme implemented many of the qualitative criteria for ESD-schools such as they are defined by Breiting et al. (2005).

Mezzo-level Supporting structure and 'Whole School Approach' are visible at this level. The concept of norm supporting structures is developed by the Swedish environmental education (EE) and ESD researcher Per Wickenberg (2004). The structure is often overlooked but is essential for supporting the actors, key actors or deciding individuals or groups in piloting and developinging environmental ESD programmes at a local level and trying to integrate new legislations, a curriculum, a syllabus, etc.

The educational system's priority of natural science and STEM subjects before social and human science in ESD is a hurdle for supporting a restructuring to a more holistic view on ESD. Another example of norm supporting structure, as long as they are given adequate opportunity to act, are the dedicated key individuals within the school; for instance, interested colleagues and workmates. This of course requires the active support and participation of the headmaster and the school board. External persons and other resources that may be mobilized to support the processes of influence is also a supporting element. Clear goals of environmental and ESD teaching are essential (Wickenberg 2004, p.115-116). These norm supporting structures were not all visible in the GLAD programme. Even though there was an acceptance from the TTI principals and management, it was still a challenge to have a clear commitment from the overall University College management. Healey mentioned: "Partnership is more likely to be sustained where there is a strong sense of community among staff and student" $(2014$, p. 8) and this seems to be clear in the GLAD project after the end of the external support from the donor (DANIDA). After the three-year project period ended, and the University College had to develop it further, it was not possible to continue.

At Mezzo-level the GLAD project was relevant not only in relation to the normfactors but also "the whole institution (or school) approach":. "A whole-school approach to ESD calls for sustainable development to be integrated throughout the formal sector curriculum in a holistic manner, rather than being taught on a stand-alone basis" (Hargreaves 2008, p.69). This approach means that it will not only be the teaching and learning of sustainable development that are involved, but also the whole school operation with stakeholders, local community involvement, long-term planning, sustainability monitoring and evaluation. In that sense, the

146

Teacher Education and Co-Learning with ESD

Futures of Education, Culture \& Nature - Learning to Become 
whole-school approach actively involves and integrates all aspects of sustainable development, not only economically, but also socially, environmentally, and culturally. The GLAD programme did integrate parts of the curriculum (geography), the school placement (for the Danish teacher students in Kenya), visits for lecturers from Kenya and the paid lessons given to the lecturers in Denmark.

Annette Gough (2005) gives a good example of a Ten-Step plan which is designed as an action research process for a whole school approach that includes the local community. Unfortunately, the adoption of a whole school approach and a policy that was implemented by the overall management and not only the Teacher Training Section was missing in the GLAD programme.

Macro-level global citizenship and global partnerships with partners from the Global South involving ESD is a global policy agenda, especially for UNESCO. In 2005 just before the DESD started, UNESCO released a publication: Guideline and Recommendation for Reorienting Teacher Education to Address Sustainability (UNESCO 2005) and established an international network with more than 30 teacher training institutions in just as many countries. In the policy paper, UNESCO argued for five components of a reorientation in the curriculum: knowledge, issues, skills, perspectives, and values and their interrelationship. One of the criteria was to address ESD to content, context, pedagogy, global issues, and local priorities.

The GLAD programme has many of the components and criteria integrated from the initial start and during the process, but because of weak support from the overall management and, to some extent, all lecturers - meaning the missing support from a whole school approach it was not possible to continue after the first three-year pilot project.

In 2007, UNESCO published case studies of individual and institutional efforts to reorient curriculum, programmes, practices, and policies to address sustainability at institutions of teacher education. Teacher institutions became more aware of the connection between education and sustainabily during the Decade of Education for Sustainable Development from 2005 - 2014. (UNESCO 2007). "During the Decade, ESD matured and grew. Efforts began with raising awareness, moved to capacity building, then to experimentation and finally, implementation of good practice. In effect, the Decade provided proof of concept for formal education and non-formal educational settings, including public awareness and training"... and ... "The research also identified the need to integrate ESD across all subjects, to provide professional development for teachers to ensure ESD policy implementation and to adopt ESD management practices to support ESD in the curriculum in order to broaden ESD across countries" (Laurie et al. 2016).

It became evident that at the end of DESD and at the beginning af the so-called GAP period (before the SDG) teacher education accumulated a great deal of experience in reorienting the institutions to address sustainability and infuse ESD into the TTI, curriculum, pedagogy, evaluation, and professional development programmes like the GLAD programme - even though this programme is not mentioned (McKeown \& Hopkins 2014; Hopkins \& Kohl 2020). From experience and research, we know it takes years of work to reorientate teacher education to create enduring changes.

It seems that the GLAD project has sown some seeds for ESD that were globally and locally well-oriented, but, unfortunately, never got the possibility of growing in their own garden but hopefully can inspire other teacher training institutions. 


\section{Conclusion}

The learning experiences from the GLAD programme, like many other ESD programmes working with education and sustainable development in a local and global context, is, what could be called $A$ three-layered cultural challenge between micro-, mezzo-, and macro-level (Larsen 2008).

At the individual, micro level we have personal motivation and eagerness to actively work for change towards a sustainable future in education. At the mezzo level, we are in a professional setting and work either in a public or private organization with its own culture and norms. And on the global, macro-level, we have international organizations, NGOs, or networks - like UNESCO - who have visions and policies of education for change in a sustainable direction.

The challenge for all of us is to deal with power relations, wicked problems, crises, co-creation, paradoxes, practical issues, collaborations, etc. in between the three levels. But we must deal with these cultural challenges and presssures in teaching and education for a sustainable future ${ }^{4}$.

\section{Literature}

Bovill, C. (2019). Co-creation in learning and teaching: The case for a whole-class approach in higher education. Higher Education (2020) 79:1023-1037.

Breiting, S. \& Schnack, K. (2009). Uddannelse for Bæredygtig Udvikling i danske skoler - Erfaringer fra de første TUBU-skoler i Tiåret for UBU. DPU, Aarhus Universitet.

Breiting, S.; Mayer, M.; Mogensen, F. (2005). Quality Criteria for ESD-Schools Guidelines to enhance the quality of Education for Sustainable Development. Austrian Federal Ministry of Education, Science and Culture in collaboration with the international network "Environment and School Initiatives" (ENSI) www.ensi.org.

Danida (2020). Strategic Framework: Denmark - Kenya Partnership 2021 - 2025.

Danish Initial Teacher Education (2013). Ministry of Science, Innovation and Higher Education.

Daws, J.E. (2005). Teachers and students as co-learners: possibilities and problems. Journal of Educational Enquiry, 6(1),110-125.

Delors, J. (1996). Learning: The Treasure Within. Report to UNESCO of the International Commision on Education for the Twenty-first Century. UNESCO Publishing.

Ferreira, J., Ryan, L. and Tilbury, D. (2006) Whole-School Approaches to Sustainability: A review of models for professional development in pre-service teacher education. Canberra: Australian Government Department of the Environment and Heritage and the Australian Research Institute in Education for Sustainability (ARIES).

Gough, A. (2005). Sustainable Schools: Renovating Educational Processes. Applied Environmental Education and Communication, 4:339-351. Routledge, Taylor \& Francis Group.

Gougoulakis, P. P. (2019). Educating teachers for sustainable development. In: Herrera et al. (red) Facets and Aspects of Research on Vocational Education and Training at Stockholm University. Stockholm: Premiss förlag.

IGI Global. (n.d.). What is Co-Learning, https://www.igi-global.com/dictionary/inquiry-basedlearning-on-the-cloud/52568.

4 For more inspiration on other programs with network and international partnerships look at the Wisby recommendation (SWEDESD 2017/36-39).

148

Teacher Education and Co-Learning with ESD

Futures of Education, Culture \& Nature - Learning to Become 
Hargreaves, L.G. (2008). The whole-school approach to education for sustainable development: from Pilot Projects to Systemic Change. Policy \& Practice: Education for Sustainable Development, p. 69-74.

Healey, M. et al. (2014). Engagement through partnership: students as partners in learning and teaching in higher education. The Higher Education Academy, Heslington, York. UK.

Hopkins, C. A., Kohl; K. (2020). Teacher Education Around the World: ESD at the Hearth of Education - Responsibilities and Opportunities Towards a Sustainable Future for All. Springer Link.

Højholt, A.; Ravn-Pedersen, T. (2021). Håbets og handlingens pædagogik - undervisning i verdensmål og bæredygtighed. København: Hans Reitzels Forlag.

Keen, M. et al., eds. (2005) Social Learning in Environmental Management: Towards a Sustainable Future, London: Earthscan.

Klafki, W. (1996). Core problems of the Modern World and the Tasks of Education. A Vision for International Education. In: Education: A Biennial Collection of Recent German Contributions in the Field of Educational Research, Vol. 53. Tübingen: Institut für Wissenschaftliche Zusammenarbeit.

Larsen, N. (2008). Lærerperspektiver og pædagogisk kulturmøde inden for miljøundervisning $i$ Thailand og Kenya. Ph.d.-afhandling. Danmarks Pædagogiske Universitetsskole ved Århus Universitet.

Larsen, N. et al. (2014). ICT-based, cross-cultural communication: A methodological perspective. International Journal of Education and Development using Information and Communication Technology (IJEDICT), 2014, Vol. 10, Issue 1, pp. 107-120.

Latour, B. (2018). Ned på jorden, hvordan orienterer vi os politisk? København: Informations Forlag

Laurie, R., Nonoyama-Tarumi, Mckeown, R and Hopkins, C. (2016). Contributions of Education for Sustainable Development (ESD) to Quality Education: A Synthesis of Research. Centre for Environment Education. Ahmedabad, Gujarat. Sage Publication.

Law, D.M. (2011). The Co-learning Approach to Capacity-Building and Training for Security Sector Reform Practitioners. Journal of Security Sector Management. 8(3), 1-10.

Lysgaard, J.A.; Jørgensen, N.J. (2021). Bæredygtighedens pædagogik -forskningsperspektiver og eksempler fra praksis. København: Frydenlund Academic.

Læssøe, J. (2020). Bæredygtighedsbegrebet og uddannelse. In: Andreasen, J.A. \& Jørgensen, N.J. (red), Bæredygtighedens Pædagogik -forskningsperspektiver og eksempler fra praksis. Pp. 17 - 42. Frederiksberg: Frydenlund Academic.

Jònsson, P. et al. (2021) Mapping Education for Sustainability in the Nordic Countries Ólafur. (C) Nordic Council of Ministers 2021.

McKeown, R.; Hopkins, C. (2014). Teacher Education and Education for Sustainable Development: Ending the DESD and Beginning the GAP. UNESCO.

The National Archives (n.d.). Building Effective Partnerships, https://webarchive.nationalarchives.gov.uk/ukgwa/20100420084203/http:/www.dfid.gov.uk/Documents/funding/global\%20schools/pil-section2.pdf.

Njeng'ere, K. D \& Lili J (2017). The Why, What and How of Competency-Based Curriculum Reforms: The Kenyan Experience. Series Current and Critical Issues in Curriculum, Learning and Assessment. UNESCO.

Poulsen, M. (2021). Antropocæn dannelse og bæredygtighed i gymnasiet. EMU portal from Ministry of Education in Denmark.

Republic of Kenya - Ministry of Education (2017). Education for Sustainable Development Policy for the Education Sector. 
SWEDESD (2017). Wisby Recommendations for enhancing ESD in Teacher Education. Uppsala University.

UNECE (2012). Learning for the Future - Competencies in Education for Sustainable Development. Geneva: UNECE.

UNESCO (2021). Reimagining Our Future Together - A new social contract for education. Paris.

UNESCO 17 (2021). Development Goals: UNESCO and Sustainable Development Goals

UNESCO (2020). Education for Sustainable Development: A Roadmap.

UNESCO (2015). Rethinking Education - Towards a global common goods? Paris.

UNESCO (2012). Education for Sustainable Development: Sourcebook.

UNESCO (2007). Good Practices in Teacher Education Institutions. Education for Sustainable Development in Action. Good Practices No.1. UNESCO Education Sector.

UNESCO (2005). Guideline and Recommendations for Reorienting Teachers Education to Address Sustainability. Technical Paper No.2.UNESCO Education Sector. France.

Vare, P. et al. (2019). Devising a Competence-Based Training Program for Educators of Sustainable Development: Lessons Learned. Sustainability 2019, 11, 1890.

Vare, P.; Scott W. (2007). Learning for a Change: Exploring the Relationship Between Education and Sustainable Development. Opinion Essay. SAGE Publications.

Wals, E.J. EDS.(2009). Social Learning towards a sustainable world. Principles, perspectives, and praxis. Wegeaningen Academic Publishers. Netherlands.

Wickenberg, P. (2004). Norm Supporting structures - in environmental education and education for sustainable development. In Wickenberg et al (ESD.) Learning to change our world. PP.103 - 131. Swedish research on education \& sustainable development. Studentlitteratur.

Web references for GLAD: https://www.ucviden.dk/da/projects/glad-global-learning-advanced-professionalism-dialogue. 